\title{
Optimum Strategy for Manufacturing Project of Specific Alloy for LNG Tankers Having Production Line Expansion Option under Uncertainty *
}

\author{
Akira Horiuchi, ${ }^{\mathrm{a}}{ }^{\dagger}$ Kota Isobe, ${ }^{\mathrm{b}}$ and Gento Mogi ${ }^{\mathrm{b}}$ \\ a Yakin Kawasaki Co., Ltd. \\ b School of Engineering, The University of Tokyo
}

\begin{abstract}
Due to the growing demand and increase in size of LNG (Liquefied Natural Gas) tankers throughout the world, increasing demand for larger size specific alloy membrane made of so called Invar (specific alloy of iron and nickel with extremely low thermal coefficient of expansion) is expected. Two major producers compete in a large scale Invar membrane business, as a leader and a follower, both having distinctive options for production line expansion in the future. Optimum strategies both for leader as well as follower in such a competitive duopoly condition have been derived based on real options analysis combined with game theory.
\end{abstract}

Keywords: Real options; capacity investment; game theory; duopoly; optimum strategy

*Received: June 2, 2008; Accepted: May 27, 2009.

†Corresponding author. Address: 1-5-8 Kyobashi, Chuo-ku, Tokyo 104-0031, Japan; Phone: +81-3-3273-3612; E-mail: ahu@nyk.co.jp 


\section{競合下の設備拡張オプションを有する LNG タンカー用特殊合金製造事業の最適戦略}

堀内晃 $\mathrm{a}$, 磯部航太 $\mathrm{b}$, 茂木源人 $\mathrm{b}$

a (株)YAKIN 川崎

$b$ 東京大学大学院工学系研究科

\section{1 はじめに}

ステンレス鋼は世界的に見れば成長性は高いものの，BRIC'S と呼ばれる国々など，ある限 られた地域での成長が主体となっている，米国や日本などでは，あまり大きな成長性は認めら れず，むしろ成熟市場とみなした方が妥当である。このような状況での既存メーカーの生き残 り策として実際に多く見られる戦略は，経営統合を行って企業体力を向上させるというもので ある。しかし既存メーカーの生き残り策はこれだけではないであろう．大きな生産規模に見合 わない品種に移行し，狭い領域の”すきま”市場を狙う戦略も考えられる.

本論文においては，ある市場において既に圧倒的なシェアを持つメーカー（多くの場合先行 メーカーである）とシェアの小さいメーカー（多くの場合後発メーカーである）の二社による 複占市場を考え，両者が製造能力の拡大投資を行う場合の最適戦略を求めた.

この設定は既存のステンレス鋼メーカーがステンレスではない特殊な合金を製造する状態を 想定している，すなわちステンレス鋼に比べれば市場の小さい，しかしながらある程度の成長 が見込まれる”すきま”市場において二社の複占状態を想定し，二社双方が製造能力の拡大投資 を行う場合の最適戦略を, 各種パラメータを多様に変化させることによって導き出すことを目 的とした.

投資可否判断を行うためにはその投資活動の事業価値を評価しなければならない，企業の意 思決定に際して，事業価值を正確に評価することの重要性は広く認識されており，NPV 法をは じめとして様々な手法が開発されてきた．現在は，NPV 法の欠点を補うものとして，将来の不 確実性を柔軟に記述することのできるリアルオプション理論および競合状態における最適戦略 を導出することのできるゲーム理論を用いた事業評価手法の開発が盛んに行われている. 
この分野における代表的な研究としては, Smit and Ankum[8], Dixit and Pindyck[2], Grenadier[4]，Huisman[5]，Weeds[9]などが挙げられる. Smit and Ankum は，決定木を用 いた 3 時点のツリーモデルを構築し, 数值例を用いた結果を示している. 一方, Dixit and Pindyck は, 微分方程式を用いた解析により, 不確実性下における産業全体の均衡戦略を導出 している. Grenadier は不動産市場における最適な投資タイミングについての分析を行った. Huisman は Fudenberg and Tilore[3]によるタイミング・ゲームの考え方に対し, 需要の不確 実性を加味することで，不確実性下における競合状態を記述した．Weeds は，複占市場におけ る R\&D 競争に対して, 取得する特許の価值が不確実であるという条件を与えた上で, 投資が 持つ価值を分析している.

このように, 競争条件下におけるリアルオプションの解法には, 様々な手法が存在している. これらの手法については, 時間を連続的に捉え, 微分方程式を構築する手法と, 時間を離散的 に捉え，ツリーモデルを構築する方法という二種類に大きく分類することができる．しかし， この二種類の手法には, 現実の投資案件を分析するにあたり, それぞれ大きな欠点が存在する.

現在主流になっている微分方程式を構築し, 解析解を得るという手法は, 解が得られた場合 には各パラメータの相互関係を直観的に理解することが可能となるが，複雑な条件下では，解 析解を得ることが難しい. 特に, 将来の不確実性や競合他社の動向に加え, 固定費および変動 費の構造や企業間のシェアなどが投資意思決定に密接に関わってくる製造業においてリアルオ プション分析をする場合には，この欠点がより顕著になってくる．一方，Smit and Ankum の ように, プロジェクト期間を少数の時点に区切るツリーモデルでは, 導出した解が多くの誤差 を含んでいる可能性を否定することができないという久点がある.

これらの久点を補う形で開発されたモデルとして, Murto et al.[7]や Imai and Watanabe[6] がある。これらの論文では，将来が不確実な中で複数の企業が投資オプションを保有している 状況を，多期間の投資ゲームと捉え，リアルオプション価值の定量的な評価を可能にした．し かし，両モデルともにツリーモデルをべースにしているため，原資産の過程が複雑になった場 合や，複数の原資産を持つ場合などには，これらのモデルを適用寸ることができない．また， 計算方法をモデル化することに重点が置かれているため, 感度分析の幅が狭いものとなってい る. たとえば, Murto et al.はモデル化の段階では変動費の概念を導入しているものの, 例とな るケースでは, 企業の変動費をゼロに固定しており, この值についての感度分析は行われてい ない.

我々の究極的な目的は, 合金製造事業における事業環境分析の統一的なツールを開発し,様々 な合金市場における最適投資戦略を導くことである，そのためには，原資産過程が複雑である 
場合にも十分対応しうるモデルを構築することが望ましい，また，本稿では原資産は 1 つであ るが，今後の拡張性を考慮すると，複数の原資産を持つ場合にも柔軟に対応できることは大き な利点となる.

ここで，我々は，Barraquand and Martineau[1]によって開発された，多資産からなるアメ リカン・オプション価值を算出する際の強力なシミュレーション手法である SSA (Stratified State Aggregation）法に注目した. SSA 法はモンテカルロ法を用いた計算手法であるが，状態 空間を複数のセルに分割するという点に特徵がある。セルの分割ができれば，ツリーモデルと 類似した後進アルゴリズムでオプション価值を算出できるため，ツリーモデルとの親和性が高 い. また, SSA 法はコンパウンド・オプション分析への応用が可能であるという点も注目に值 する，例えば，安達ら[10]が，SSA 法の改良により，探査や開発など複数の投資ステージを持 つ資源開発プロジェクトのリアルオプション評価を行っている.

そこで，本稿では，Imai and Watanabeの多期間投資ゲームのモデルに対し，SSA 法のア ルゴリズムを適用し，企業の複雑なキャッシュフロー構造について，現実性を損なうことなく 柔軟に記述することのできるモデルを開発する，その上で，このモデルに対して，LNG タンカ 一用特殊合金事業におけるケースを適用し，企業の費用構造を固定費と変動費に分類すること や，企業間におけるシェアなどをモデリングした上で，事業価值や一定期間内で投資を行う確 率を算出し，そこから得られる示唆について詳細に分析する.

本稿の構成は以下のとおりである. 1 節では，本稿の目的について記述した． 2 節では，開 発した事業価值評価モデルについて説明する．３節では，適用したケースについて具体的に記 述する. 4 節では，シミュレーションの結果について記述する５節では，事業価值に影響を 与えると考えられる様々なパラメータに対し, 感度分析を行い, そこから得られる示唆につい て考察する.最後に, 6 節で本稿のまとめを行う.

\section{2 モデルについて}

\section{1 基本的な設定}

本稿で想定する競合状態とは，一方の意思決定がもう一方のキャッシュフローに直接的に影 響を及ぼす複占市場において，両企業がそれぞれ事業を拡張する機会（拡張オプション）を同 時に保有しているという状態である. 以後, それぞれの企業を, 相対的に地位の高いリーダー 企業と, リーダー企業に追随するフォロワー企業という意味で, 企業 $L$, 企業 $F$ と呼ぶ.両企業 はともに，一定の期間内において毎期発生するキャッシュフローの現在価值の合計を最大化す るために最適な判断をするものとして，両企業の事業価值を算出する. なお，判断の際には， 
両企業ともに,相手企業のキャッシュフローに関する情報を全て把握しているものとした.

通常は事業を拡張する際には投資意思決定直後から投資が完了するまでに一定の時間がかか るが, 本稿では単純化のために投資の意思決定をした瞬間に投資が完了するものとした. また， 投資は 1 度しか行えず，かつ不可逆であるとした．キャッシュフローについては，市場の状態 および両企業の投資状態に応じて毎期発生するものとした.

\subsection{SSA 法を用いたモンテカルロシミュレーションによる事業価值評価のアルゴリズム}

本節では, Barraquand and Martineau によって開発された SSA 法および Imai and Watanabe によって開発された不確実性を考慮した多期間の投資ゲームのモデルを応用したモ ンテカルロシミュレーションによる事業価值評価のアルゴリズムを記述する. 表記方法は湯前, 鈴木[11]を参考にした. アルゴリズムは以下の 4 つのステップに従う.

\section{ステップ $1:$ 状態空間のセル化}

まず，満期 $T$ までの期間を $M$ 個に分割し，それぞれの時点を $t_{j}(j=0, \cdots, M)$ とおく. 原資産 の第 $i(i=1, \cdots, N)$ パスにおける值を $S_{j}(i)$ と表寸. $S_{j}(i)$ は，第 $j$ 期における市場の状態を表し ている. 原資産パスに対して, キャッシュフローは, $X_{j}(i)=h\left(S_{j}(i)\right)$ と定義される関数と各企 業の投資状態から求まるものとする.

ここで， $X_{j}$ の值域を $K$ 個の区間に分割する. 各区間を $C_{j}^{k}=\left[c_{j}^{k}, c_{j}^{k+1}\right)(k=1, \cdots, K)$ とし， $X_{j} \in C_{j}^{k}$ のとき $X_{j}$ は状態 $k$ にいると表現する. 本稿におけるセルの分割方法は次節で述べる.

\section{ステップ 2 : サンプルパスの発生と推移確率の算出}

原資産パス $S(i)$ を $N$ 本発生させ, $X_{j}(i) \in C_{j}^{k}$ となるパスの数 $a_{j}(k)$ をカウントする. 同様に, $X_{j}(i) \in C_{j}^{k}$ となるパスの数をカウントする. このとき

$$
\pi_{j}(k, l)=\frac{b_{j}(k, l)}{a_{j}(k)}
$$

を計算し, これを推移確率と呼ぶ.また, セル $C_{k}^{j}$ における $X_{j}$ の平均值

$$
g_{j}(k)=\frac{\sum_{X_{j} \in C_{j}^{k}} X_{j}}{a_{j}(k)}
$$


を計算しておく。

ステップ 3 : 後進アルゴリズムによる事業価值の算出

時点 $t_{j}$ における企業 $i(i=L, F)$ の投資状態を $x_{i}(j)$ で表わす. なお，投資が完了している状態 を”in”, 完了していない状態を”out”と表記する. また, 各企業の投資コストを $I_{L}, I_{F}$ とする.

時点 $t_{j}$, 状態 $k$ における投資コストを除いたキャッシュフローを $g_{j}(k)$ の関数とし, 投資状 態に応じた企業 $i$ のキャッシュフローを $C F_{i}^{\left(x_{L}(j) x_{F}(j)\right)}\left(g_{j}(k)\right)$ と表す. また, 時点 $t_{j}$, 状態 $k$ にお ける投資状態に応じた企業 $i(i=L, F)$ の事業価值 $V_{i}$ をそれぞれ $V_{i}^{\left(x_{L}(j), x_{F}(j)\right)}\left(t_{j}, k\right)$ と表す.

プロジェクト終了時点である満期 $t_{M}=M$ については，キャッシュフローが発生しない，す なわち,

$$
C F_{i}^{\left(x_{L}(j), x_{F}(j)\right)}\left(g_{M}(k)\right)=0
$$

とする。また，

$$
V_{i}^{\left(x_{L}(j), x_{F}(j)\right)}\left(t_{M}, k\right)=0
$$

とする.

時点 $t_{j}<t_{M}=M$ について, 全てのセルの各投資状態における事業価值を求めるが，その前 に時点 $t_{j}$, 状態 $k$ における投資意思決定直後の投資コストを除いた両企業の事業価值を $v_{i}^{\left(x_{L}(j), x_{F}(j)\right)}\left(t_{j}, k\right)$ とし, 以下の式に従って計算しておく.

$$
v_{i}^{\left(x_{L}(j), x_{F}(j)\right)}\left(t_{j}, k\right)=C F_{i}^{\left(x_{L}(j), x_{F}(j)\right)}\left(g_{j}(k)\right)+e^{-r\left(t_{j+1}-t_{j}\right)} \sum_{l=1}^{K} \pi(k, l) V_{i}^{\left(x_{L}(j), x_{F}(j)\right)}\left(t_{j+1}, l\right)
$$

ここで， $r$ は割引率を表す。本稿における割引率の取り扱いについては次節で記述する.

以下ではそれぞれの投資状態に応じた後進アルゴリズムを説明する.

- $($ in, in $)$ の場合

この場合は両企業ともに投資を完了しているため, 意思決定を考慮する必要は無く,

$$
V_{i}^{(i n, i n)}\left(t_{j}, k\right)=v_{i}^{(i n, i n)}\left(t_{j}, k\right)
$$

となる。

- (in,out) の場合

この場合は企業 $F$ のみが意思決定を行う．企業 $F$ が投資をしたときの企業 $F$ の事業価値を 
$e_{F}^{(i n, \text { out })}\left(t_{j}, k\right)$, 投資をしなかつたときの企業 $F$ の事業価值を $w_{F}^{(i n, \text { out })}\left(t_{j}, k\right)$ とおくと, それぞれ

$$
\begin{gathered}
e_{F}^{(\text {in,out })}\left(t_{j}, k\right)=v_{F}^{(\text {in,in })}\left(t_{j}, k\right)-I_{F} \\
w_{F}^{(\text {in,out })}\left(t_{j}, k\right)=v_{F}^{(\text {in,out })}\left(t_{j}, k\right)
\end{gathered}
$$

と表される.したがって，

$$
V_{F}^{(\text {in,out })}\left(t_{j}, k\right)=\max \left[e_{F}^{(\text {in out })}\left(t_{j}, k\right), w_{F}^{(\text {in out })}\left(t_{j}, k\right)\right]
$$

となる.一方, 企業 $L$ の事業価值は,

$$
V_{L}^{(\text {in,out })}\left(t_{j}, k\right)= \begin{cases}v_{L}^{(i n, \text { in })}\left(t_{j}, k\right) & \text { if } e_{F}^{(\text {in,out })}\left(t_{j}, k\right)>w_{F}^{(i n, \text { out })}\left(t_{j}, k\right) \\ v_{L}^{(i n, \text { out })}\left(t_{j}, k\right) & \text { otherwise }\end{cases}
$$

となる。

- (out,in)の場合

この場合は前述した (in, out $)$ の場合と同様に計算できる. 企業 $L$ が投資をしたときの企業 $L$ の事業価值を $e_{L}^{(\text {out }, \text { in })}\left(t_{j}, k\right)$, 投資をしなかったときの企業 $L$ の事業価值を $w_{L}^{(o u t, i n)}\left(t_{j}, k\right)$ とおくと, それぞれ

$$
\begin{gathered}
e_{L}^{(\text {out }, \text { in })}\left(t_{j}, k\right)=v_{L}^{(\text {in,in })}\left(t_{j}, k\right)-I_{L} \\
w_{L}^{(\text {out }, \text { in })}\left(t_{j}, k\right)=v_{L}^{(\text {out,in })}\left(t_{j}, k\right)
\end{gathered}
$$

と表される。しだって，

$$
V_{L}^{(\text {out }, \text { in })}\left(t_{j}, k\right)=\max \left[e_{L}^{(\text {out }, \text { in })}\left(t_{j}, k\right), w_{L}^{(\text {out }, \text { in })}\left(t_{j}, k\right)\right]
$$

となる. 一方, 企業 $F$ の事業価值は,

$$
V_{F}^{(\text {out }, \text { in })}\left(t_{j}, k\right)= \begin{cases}v_{F}^{(\text {in, in })}\left(t_{j}, k\right) & \text { if } e_{L}^{(\text {out }, \text { in })}\left(t_{j}, k\right)>w_{L}^{(\text {out }, \text { in })}\left(t_{j}, k\right) \\ v_{F}^{(\text {out }, \text { in })}\left(t_{j}, k\right) & \text { otherwise }\end{cases}
$$

となる。 


\section{堀内 晃・磯部航太・茂木 源人}

- (out, out) の場合

この場合には，両企業ともに意思決定を行う必要があり，均衡戦略を求めるためにゲーム理 論の考え方を応用する．ここで，企業 $L$ に意思決定の優先権があるとする．一方で企業 $F$ は， 両企業ともに自企業の事業価值を最大化するよう意思決定を行うという仮定から，企業 $L$ の意 思決定に対して最適に反応するものとする。したがって，企業 $L$ は投資をする場合としない場 合のそれぞれについて，前もって企業 $F$ の反応を知ることができるため，意思決定を有利に行 うことができる。

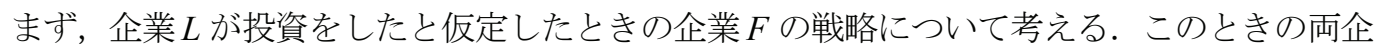
業の事業価值を $V_{i}^{L_{i n}}\left(t_{j}, k\right)(i=L, F)$ とおく. 企業 $F$ が投資をしたときの企業 $F$ の事業価值を $e_{F}^{L_{i n}}\left(t_{j}, k\right)$, 投資をしなかったときの企業 $F$ の事業価値を $w_{F}^{L_{i n}}\left(t_{j}, k\right)$ とおくと，それぞれ，

$$
\begin{aligned}
& e_{F}^{L_{\text {in }}}\left(t_{j}, k\right)=v_{F}^{(i n, \text { in })}\left(t_{j}, k\right)-I_{F} \\
& w_{F}^{L_{\text {in }}}\left(t_{j}, k\right)=v_{F}^{(i n, \text { out })}\left(t_{j}, k\right)
\end{aligned}
$$

と表される.したがって，

$$
V_{F}^{L_{i n}}\left(t_{j}, k\right)=\max \left[e_{F}^{L_{i n}}\left(t_{j}, k\right), w_{F}^{L_{i n}}\left(t_{j}, k\right)\right]
$$

となる，一方，企業 $L$ の事業価値は，

$$
V_{L}^{L_{\text {in }}}\left(t_{j}, k\right)= \begin{cases}v_{L}^{(i, \text {,in })}\left(t_{j}, k\right)-I_{L} & \text { if } e_{F}^{L_{\text {in }}}\left(t_{j}, k\right)>w_{F}^{L_{\text {in }}}\left(t_{j}, k\right) \\ v_{L}^{(i, \text { out })}\left(t_{j}, k\right)-I_{L} & \text { otherwise }\end{cases}
$$

となる.

次に，企業 $L$ が投資をしなかったと仮定したときの企業 $F$ の戦略を考える．このときの両企 業の事業価值を $V_{i}^{L_{\text {oum }}}\left(t_{j}, k\right) \quad(i=L, F)$ とおく. 企業 $F$ が投資をしたときの企業 $F$ の事業価値を $e_{F}^{L_{o u t}}\left(t_{j}, k\right)$, 投資をしなかったときの企業 $F$ の事業価值を $w_{F}^{L_{o u t}}\left(t_{j}, k\right)$ とおくと, それぞれ

$$
e_{F}^{L_{\text {out }}}\left(t_{j}, k\right)=v_{F}^{(\text {out }, \text { in })}\left(t_{j}, k\right)-I_{F}
$$




$$
w_{F}^{L_{\text {out }}}\left(t_{j}, k\right)=v_{F}^{(\text {out }, \text { out })}\left(t_{j}, k\right)
$$

と表される.したがって，

$$
V_{F}^{L_{\text {out }}}\left(t_{j}, k\right)=\max \left[e_{F}^{L_{\text {out }}}\left(t_{j}, k\right), w_{F}^{L_{\text {out }}}\left(t_{j}, k\right)\right]
$$

となる，一方，企業 $L$ の事業価値は，

$$
V_{L}^{L_{\text {out }}}\left(t_{j}, k\right)= \begin{cases}v_{L}^{\text {out, in })}\left(t_{j}, k\right) & \text { if } e_{F}^{L_{\text {out }}}\left(t_{j}, k\right)>w_{F}^{L_{\text {out }}}\left(t_{j}, k\right) \\ v_{L}^{\text {(out, out })}\left(t_{j}, k\right) & \text { otherwise }\end{cases}
$$

となる。

最後に, 均衡戦略を求める. 均衡戦略は $V_{L}^{L_{\text {in }}}$ と $V_{L}^{L_{\text {out }}}$ の大小によって決定され, (out, out $)$ のと きの企業 $L$ の事業価值は,

$$
V_{L}^{(\text {out }, \text { out })}\left(t_{j}, k\right)= \begin{cases}V_{L}^{L_{\text {in }}}\left(t_{j}, k\right) & \text { if } V_{L}^{L_{\text {in }}}>V_{L}^{L_{\text {out }}} \\ V_{L}^{L_{\text {out }}}\left(t_{j}, k\right) & \text { otherwise }\end{cases}
$$

となる，一方，のときの企業 $F$ の事業価値は，

$$
V_{F}^{\text {(out }, \text { out })}\left(t_{j}, k\right)= \begin{cases}V_{F}^{L_{\text {in }}}\left(t_{j}, k\right) & \text { if } V_{L}^{L_{\text {in }}}>V_{L}^{L_{\text {out }}} \\ V_{F}^{L_{\text {out }}}\left(t_{j}, k\right) & \text { otherwise }\end{cases}
$$

となる。

以上の後進アルゴリズムを初期時点である時点 0 まで繰り返す過程を通して, 各時点, 各セ ル，各投資状態で投資の意思決定，すなわちオプションの行使・非行使の選択を行った. これ をもとに各投資状態に応じて状態空間を行使と非行使に選別したマップを作成する.

\section{ステップ $4:$ 再評価および静的な事業価値の計算}

再度 $N$ 本のパスを発生させ，ステップ 3 で作成した行使・非行使マップに基づいて行使・非 行使を決定する．事業価值は各パスの投資コストを含めたキャッシュフローの平均值として求 めることができる.

同時に，投資延期のオプションを考慮しないときの事業価値を，時点 0 で両企業とも投資す る場合，時点 0 で企業 $L$ のみ投資し企業 $F$ は最終時点まで投資しない場合，時点 0 で企業 $F$ の 
み投資し企業 $L$ は最終時点まで投資しない場合，両企業とも最終時点まで投資しない場合につ いてそれぞれ計算する.

\section{3 事業への適用}

\section{1 適用した事業の説明}

本稿では，競合を考慮したリアルオプション分析による事業評価の適用例として，メンブレ ン型 LNG タンカー向けのアンバー合金製造事業を評価した。この設定は本論文冒頭で述べた ように，既存のステンレス鋼メーカーがステンレスではない特殊な合金を製造する状態を想定 している，すなわちステンレス鋼に比べれば市場の小さい，しかしながらある程度の成長が見 込まれる”すきま”市場の実例として,メンブレン型 LNG タンカー向けのアンバー合金市場を選 んだ.メンブレン型 LNG タンカーとは，アンバー合金を厚さ $0.7 \mathrm{~mm}$ ，幅 $536 \mathrm{~mm}$ ，長さ約 45 〜 $70 \mathrm{~m}$ に加工したメンブレンと呼ばれる膜状の内張り材と断熱材により高度な密閉・断熱処理 を施した LNG タンクを船体内部に配置する形式のタンカーである. ニッケル $36 \%$, 鉄 $64 \%$ の 合金であるアンバー合金は熱膨張率が非常に小さいという特徵を持っているため，バイメタル や精密機器の部品などに多く使用されているが，メンブレン型 LNG タンカー向けのアンバー 合金を製造している企業は世界で 2 社しか存在しない. この意味で，メンブレン型 LNG タン カー向けのアンバー合金市場は複占状態にあると言える.この 2 社は市場シェアにおいて大き な差があり, 高いシェアを獲得しているリーダー企業を企業 $L$, もう一方のフォロワー企業を 企業 $F$ とする.

現在, メンブレン型 LNG タンカーは 20 万 $m^{3}$ 未満級が主流であるが, 全世界の LNG 需要 が増加傾向にあることを受け, 今後はより輸送能力の高い 20 万 $m^{3}$ 超級の需要が増えると予測 されている. しかしながら, 20 万 $m^{3}$ 超級のタンカーには 20 万 $m^{3}$ 未満級に使用されるものよ り長いメンブレンを使用しなければならず，両企業ともに現行の製造設備では製造できないた め, 20 万 $m^{3}$ 超級の需要に対応するためには製造設備を増強する必要がある.

ここで，投資コストを支払うことにより 20 万 $m^{3}$ 超級の需要に対応した製造設備を手に入れ ることができるという拡張オプションを両企業が保有していると考え, 両企業の事業価值を評 価する.

なお, 本稿ではプロジェクト期間 $T$ を 25 年と置き, この期間でシミュレーションを行った. 25 年とした理由は，エネルギーの需給関係と構成が現状の延長線上にある期間を 25 年と考え たからである。また，この期間内での新規参入および既存企業の撤退はないものとした。 


\section{2 事業の不確実性について}

アンバー合金加工プラントの事業価値は，将来の需要により大きく左右される．本稿では, 将来の需要のみが不確実であるとした. 本事業においては, 各時点において, 36 ケ月分の需要 が観測可能である。一方，本稿では，詳細な戦略分析のために 1 期間 $(T / M)$ を 3 ヶ 月としい る. そこで, 36 ケ月分の需要を 12 (=36 ケ月/3 ケ月) で割った值を 1 期間分の需要と定義し, これを原資産 $Y$ とおいた。 この設定により，離散的に発生する需要をある程度スムージングす ることが可能となる.

需要 $Y$ は $t=t_{0}$ において $Y=Y_{0}$ であるとし, 以降は以下の幾何ブラウン運動に従うものとした.

$$
d Y=\mu Y d t+\sigma Y d z
$$

$\mu$ は需要のトレンドを, $\sigma$ は需要のボラティリティを示す.

また, 各期の需要は, $\lambda^{\text {over }}: \lambda^{\text {under }}$ の一定比率で 20 万 $m^{3}$ 超級タンカー向けの需要と 20 万 $m^{3}$ 未 満級タンカー向けの需要に分かれているものとする.

\section{3 保有するオプションについて}

両企業は， 1 単位あたり $I$ のコストを要する投資を $n_{i}(i=L, F)$ 単位行うというオプションを 保有しているものとする. 企業 $L$ の投資コスト $I_{L}$ は $n_{L} I$, 企業 $F$ の投資コスト $I_{F}$ は $n_{F} I$ とな る. $I$ は時間とともに変化しない定数であるとした.

この投資により，各企業は 20 万 $m^{3}$ 超級の需要に応じた製造ラインを増設し，製造能力を増 加させることができる. $\Gamma_{i}^{\text {out }}(i=L, F)$ を投資前の製造能力， $\Delta \gamma$ を 1 ライン増設したときの製造 能力の増分とすると，投資後の製造能力 $\Gamma_{i}^{i n}(i=L, F)$ は以下の式で表わされる.

$$
\Gamma_{i}^{\text {in }}=\Gamma_{i}^{\text {out }}+\Delta \gamma n_{i}
$$

\section{4 セルの分割方法について}

本稿では，各セルを通るパスの本数が等しくなるようにセル化を行った，つまり，時点 $t_{j}$ に ついてセルを $K$ 個に分ける場合, 各セルにパスが通る確率が $1 / K$ となるようにセル化を行った. さらに，最上部のセル $C_{j}^{K}$ については，さらに10 個の区間に分割した．これは，セルが極端 に広いことによる誤差を軽減するためである。これらのセルを，ダミーセルと呼ぶ．

\section{5 割引率について}

リアルオプションの研究においては，割引率としてリスク中立確率を用いるのが一般的であ る．しかし，リスク中立確率を用いることを正当化するためには，原資産と完全に相関する金 
融資産の存在性など，様々な仮定を置かなければならない．

本稿では，リスク中立的な世界の想定はせず，割引率を任意に設定した。この值は時点によ らない定数であり，両企業ともに同一の值であるとした.

\section{6 キャッシュフローについて}

キャッシュフローは毎期発生し，投資状況に応じた製造能力および次項で説明する発注シェ アに応じた製造量をもとに，次式で決定されるものとした．

キャッシュフロー $(/$ 期 $)=$ 製造量 $(t o n) \times\{$ 販売単価 $(/ t o n)$ - 変動費 $(/ t o n)\}$-固定費

製造量の決定方法は 3.7 節および 3.8 節で，また，変動費および固定費の算出方法について は 3.9 節で記述する．その上で，3.10 節において(27)式を再度定式化する.

\section{7 発注シェアについて}

需要量のうちそれぞれの企業に発注される量の割合を発注シェアと定義し，これを $\theta_{i}(i=L, F)$ とおく，投資をしているかいないかで場合が分かれるが，いずれにしても，発注シ エアは両企業が競合する大きさの船に対するシェアとなる.

\subsection{1 両企業ともに投資している場合}

両企業がともに投資をしている場合は, 発注シェアは単純に全需要量のうちそれぞれの企業 に発注される量の割合である。

\subsection{2 一方だけが投資している場合}

一方だけが投資し，もう一方が投資を見合わせている場合は，当然のことながら，投資を行 った企業だけが 20 万 $m^{3}$ 超級の船の材料供給が可能になる．したがって，投資を行った企業が 20 万 $m^{3}$ 超級向けの需要を独占する. 投資を行っていない企業は 20 万 $m^{3}$ 未満級向けの供給の みを行う.ここで, 投資を行った企業も 20 万 $m^{3}$ 未満級向けの材料供給は可能である.よって， 一方だけが投資し，もう一方が投資を見合わせている場合の発注シェアは，20 万 $m^{3}$ 未満級向 け需要のうちそれぞれの企業へ発注される割合とした. 投資したラインそのものにおいても 20 万 $m^{3}$ 未満級向けの製造は可能なのでこれも考慮した.

\subsection{3 両企業ともに投資を見合わせている場合}

両者ともに投資を見合わせている場合, この場合も発注シェアは単純に全需要量のうち自企 
業に発注される量の割合になる。

なお，この状態では， 20 万 $m^{3}$ 超級の需要を満たせる企業が存在しない．このときには， 20 万 $m^{3}$ 超級の需要は船舶数ベースで $\eta$ の割合で 20 万 $m^{3}$ 未満級の需要へと置き換えられるもの とした. 20 万 $m^{3}$ 未満級タンカーに用いられるアンバー合金の量は 20 万 $m^{3}$ 超級に用いられる 量の $80 \%$ であるので, このときの総需要量は, 潜在的な需要 $Y$ に対して $\left(0.8 \eta \lambda^{\text {over }}+\lambda^{\text {under }}\right) Y$ とな る.これが発注シェアに基づいて各企業に発注されるものとした.

\section{8 需要配分（＝製造量）について}

両企業の 1 期あたりの製造量は，発注シェアに基づいた需要家からの発注量とそれぞれの製 造能力に従って決定される.

\subsection{1 両企業ともに製造能力以下の発注を受けた場合}

この場合は単純である。それぞれ，発注量と同じ量の製造を行う。

\subsection{2 一方が製造能力を上回る発注を受けた場合}

発注シェアに基づき需要量を配分した後の状態で一方が製造能力を上回る発注を受け，もう 一方に製造余力がある場合は，オーバーフローした需要を余力がある側が埋めるものとした.

\subsubsection{1 両社ともに投資を行っている場合, および両社ともに投資を行っていない場合}

この場合は特別な考慮は不要である.オーバーフローした需要がそのまま余力がある側への 需要へと移る.

\subsubsection{2 一方だけが投資を行っており，投資を行った企業の需要配分が製造能力を超えた場合}

投資を行った企業は 20 万 $m^{3}$ 超級の発注分を独占することは既に述べたが，その製造能力が 20 万 $\mathrm{m}^{3}$ 超級の発注分の需要を満たせない場合は, オーバーフローした需要は重量比 $80 \%$ の割 合で 20 万 $m^{3}$ 未満級の需要へと置き換えられ，投資を行っていない側への発注へ代替されるも のとした.

一方の企業だけが投資を行ったときの発注シェアは 20 万 $m^{3}$ 未満級向けへの発注シェアであ ることは既に述べた. 投資を行った企業への 20 万 $\mathrm{m}^{3}$ 超級と 20 万 $\mathrm{m}^{3}$ 未満級を合わせた需要配 分がこの企業の製造能力を上回る場合, 20 万 $m^{3}$ 未満級向けの需要が先に投資を行っていない 企業への発注へ移るものとした. 


\subsubsection{3 一方だけが投資を行っており, 投資を行っていない企業の需要配分が製造能力を超え た場合}

この場合, オーバーフローする需要は 20 万 $m^{3}$ 未満級のものだけになるので，単純にオーバ ーフローした分がそのまま投資を行った企業への発注となるものとした.

\subsection{3 両企業ともに製造能力以上の発注を受けた場合}

以上のような計算に基づいた結果，または当初から各期でオーバーフローした需要（注残） が両社に生じた場合，それぞれの企業は自らの製造能力いつぱいまでの製造を行う。オーバー フローした需要は次の期に持ち越されず，各期でキャンセルされるものとした.

\section{9 両企業の変動費と固定費について}

企業 $L$ と企業 $F$ のうち, 企業 $F$ の変動費, 固定費, 販売単価が判っているものとする. ここ で，比較を容易にするために，以下の二つの仮定をおく．

(1)両企業の変動費は同じ，すなわち両企業ともに企業努力を重ね，ほぼ同等のコストダウン を達成しているものとする。

(2)販売単価は市場が均衡状態にあると考え，同一とする.

この仮定により, 製造 1 単位あたりの利益は, 両企業同一の值をとることになる. この值を $\rho$ とおく.

固定費については，企業 $F$ の各值を既知とし，企業 $L$ の固定費を以下の手順で計算する.

\subsection{1 人件費}

両企業の従業員数から求める. なお, 今回の例では企業 $F$ が日本国内であるのに対し, 企業 Lはフランスに存在するものとし, 日本とフランスの一人当たり GDP 比を考慮した.

企業 $L$ 全従業員数 : $M_{L}$

企業 $F$ の全従業員数 : $M_{F}$

企業 $L$ の $\mathrm{Fe}-\mathrm{Ni}$ 合金製造のみに従事している従業員数： $M_{L i}$

企業 $L$ の人件費総額 : $B_{L 1}$

企業 $F$ の人件費総額 : $B_{F 1}$

日仏の一人当たり GDP 比 : 1:0.858

企業 $L$ の全製造量 : $P_{L}$ 
企業 $L$ の $\mathrm{Fe}-\mathrm{Ni}$ 合金製造量 : $P_{L i}$

企業 $L$ の $\mathrm{Fe}-\mathrm{Ni}$ 合金製造にかかる人件費 : $b_{L 1}$

労務費は，アンバー合金の製造のみに従事している従業員の分と，それ以外の従業員の分と を分けて計算する.

まず，企業全体の労務費を両企業の従業員数の比と GDP 比から求める.

$$
B_{L 1}=B_{F 1} \frac{M_{L}}{M_{F}} \times 0.858
$$

アンバー合金の製造のみに従事している従業員の分は，労務費の総額から按分して求める.

$$
B_{L 1} \frac{M_{L i}}{M_{L}}
$$

アンバー合金以外の製造にも従事している従業員の配賦分は，まず人数分を労務費総額から 按分して求めた後，全製造量に対するアンバー合金の製造量の比を掛けて求める.

$$
B_{L 1}\left(1-\frac{M_{L i}}{M_{L}}\right) \frac{P_{L i}}{P_{L}}
$$

以上二つを合計して企業 $L$ の $\mathrm{Fe}-\mathrm{Ni}$ 合金製造にかかる人件費 $b_{L 1}$ を求める.

$$
b_{L 1}=B_{L 1} \frac{M_{L i}}{M_{L}}+B_{L 1}\left(1-\frac{M_{L i}}{M_{L}}\right) \frac{P_{L i}}{P_{L}}
$$

\section{9 .2 人件費以外の固定費}

人件費以外の固定費は設備維持費用や減価償却費が主たるものとなる。これらは設備のライ ン数や規模に比例すると考えられ，さらにそれは製造量に概略比例すると考えられる．したが って,

企業 $L$ の全製造量 : $P_{L}$

企業 $F$ の全製造量 : $P_{F}$

企業 $L$ の $\mathrm{Fe}-\mathrm{Ni}$ 合金製造量 : $P_{L i}$

企業 $L$ の人件費以外の固定費総額 : $B_{L 2}$

企業 $F$ の人件費以外の固定費総額 : $B_{F 2}$

企業 $L$ の $\mathrm{Fe}-\mathrm{Ni}$ 合金製造にかかる人件費以外の固定費： $b_{L 2}$ として, 次の式から求めた.

$$
B_{L 2}=B_{F 2} \frac{P_{L}}{P_{F}}
$$




$$
b_{L 2}=B_{L 2} \frac{P_{L i}}{P_{L}}
$$

以上より，企業 $L$ の合金製造にかかる固定費総額 $b_{L}$ は上記の合計となる.

$$
b_{L}=b_{L 1}+b_{L 2}
$$

また，損益分岐点となる製造量を製造能力で割った值を，固定費用係数と呼び，これを $\chi_{i}(i=L . F)$ とおく. 固定費用係数が小さいほど, より少ない製造量で利益を上げることが可能 となる。

\subsection{0 キャッシュフローの定式化}

まず，前節で定義した固定費用係数 $\chi_{i}$ を用いて毎期の固定費を定式化することを考える.

固定費用係数は損益分岐点となる製造量を製造能力で割った值として定義した。これは，製 造能力 $\Gamma_{i}^{x_{i}(j)}$ に対して $\chi_{i}$ だけの割合を製造したときの売上高から変動費分を引いた值が固定費 に等しいということを意味している，これより，毎期の固定費は製造 1 単位あたりの利益 $\rho$ を 用いて， $\rho \chi_{i} \Gamma_{i}^{x_{i}(j)}$ と書くことができる.

したがって，当期の製造量を $q$ とすると，各企業の各時点，各投資状態における投資コスト を除いたキャッシュフローは，(27)式の変形により，以下のように記述できる.

$$
\begin{aligned}
C F_{i}^{\left(x_{L}(j), x_{F}(j)\right)} & =\rho q-\rho \chi_{i} \Gamma_{i}^{x_{i}(j)} \\
& =\rho\left(q-\chi_{i} \Gamma_{i}^{x_{i}(j)}\right)
\end{aligned}
$$

この関係を図示したものを図 1 に示す，横軸は $q$ であり，縦軸は $C F$ である，上記のような 仮定をおいたことにより，CF は $q$ の一次関数で表わすことができる.

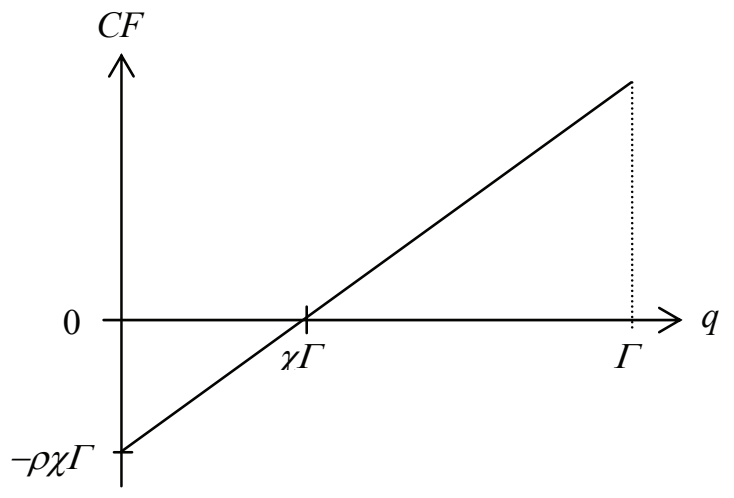

図 1: 製造量とキャッシュフローの関係

\subsection{1 ベースケースのパラメータについて}

以上の仮定をもとに, ベースケースとして, 表 1 の数值を代入した. なお, 金額については, 
1 ラインあたりの投資コスト $I$ を 100 とし，正規化を行った.

表 1: ベースケースのパラメータ

\begin{tabular}{|c|c|c|c|}
\hline 表記 & 内容 & 值 & 単位 \\
\hline$T$ & プロジェクト期間 & 25 & 年 \\
\hline$M$ & プロジェクト期間の分割数 & 100 & 期 \\
\hline$r$ & 割引率 & 4.50 & $\%$ \\
\hline$Y_{0}$ & プロジェクト開始時における需要 & 15 & - \\
\hline$\mu$ & 需要のトレンド & 1.97 & $\%$ \\
\hline$\sigma$ & 需要のボラティリティ & 17.6 & $\%$ \\
\hline$\lambda^{\text {over }}$ & 全需要における 20 万 $m^{3}$ 超級タンカー用の需要の割合 & 54 & $\%$ \\
\hline$\lambda^{\text {under }}$ & 全需要における 20 万 $m^{3}$ 未満級タンカー用の需要の割合 & 46 & $\%$ \\
\hline$\rho$ & 製造 1 単位あたりの利益 & 13.4 & - \\
\hline$\Gamma_{L}^{\text {out }}$ & 企業 $L$ の拡張前の製造能力 & 18.7 & /期 \\
\hline$\Gamma_{F}^{\text {out }}$ & 企業 $F$ の拡張前の製造能力 & 3.7 & /期 \\
\hline$\Delta \gamma$ & 投資 1 ラインあたりの製造能力増分 & 4.125 & /期 \\
\hline$I$ & 投資 1 ラインあたりの拡張コスト & 100 & - \\
\hline$n_{L}$ & 企業 $L$ の増設ライン数 & 3 & - \\
\hline$n_{F}$ & 企業 $F$ の増設ライン数 & 1 & - \\
\hline$\chi_{L}$ & 企業 $L$ の固定費用係数 & 0.523 & - \\
\hline$\chi_{F}$ & 企業 $F$ の固定費用係数 & 0.399 & - \\
\hline$\theta_{L}$ & 企業 $L$ の発注シェア & 91 & $\%$ \\
\hline$\theta_{F}$ & 企業 $F$ の発注シェア & 9 & $\%$ \\
\hline$\eta$ & (out,out)における需要の代替率（船舶数ベース） & 50 & $\%$ \\
\hline$N$ & パスの本数 & $1,000,000$ & 本 \\
\hline$K$ & 1 期（3 ケ月）あたりのセルの分割数 & 100 & 個 \\
\hline
\end{tabular}

\section{4 結果}

表 2 にベースケースでの結果を示す。ここで，投資確率とは，プロジェクト満期までの間に 拡張オプションを行使する確率を示している. 
堀内 晃・磯部航太・茂木源人

表 2: ベースケースでの結果

\begin{tabular}{|c|c|c|}
\hline & 事業価値 & 投資確率(\%) \\
\hline 企業 $L$ & 1394 & $38.5 \%$ \\
\hline 企業 $F$ & 1589 & $100 \%$ \\
\hline
\end{tabular}

次に，満期までの各期における時点 0 からの累積投資確率を図 2 に示す.

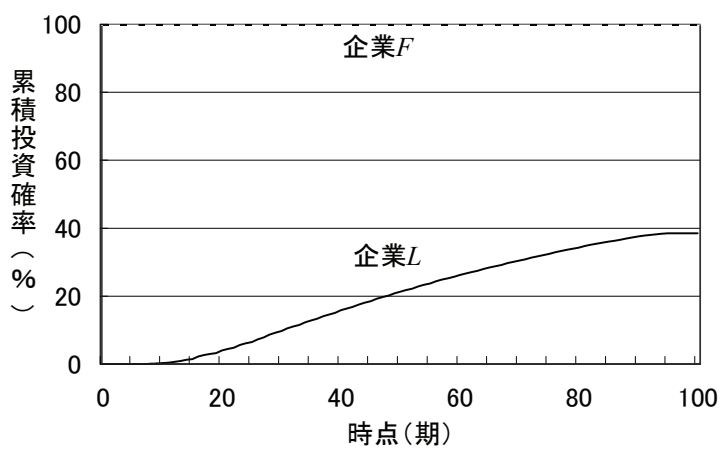

困 2：累積投資確率

今回のシミュレーションでは，企業 $F$ の投資確率が $100 \%$ となり，企業 $L$ よりも大きな事業 価值であることがわかった，これは，企業 $L$ は大きな発注シェアを持っているものの，固定費 用係数が $52.3 \%$ と大きいために，投資を見送ることが多く，製造量を多くしても大きな利益を 上げることができないためであると考えられる.

一方で，企業 $F$ としては，単独で投資を行うことで， 20 万 $m^{3}$ 超級の需要を独占できるため に，大きな事業価值が算出されているものと考えられる.

また，オプションを考慮しない，すなわち時点 0 でしか意思決定を行わないときの両企業の 事業価值を図 3 に示す.

オプションを考慮しない場合は，企業 $F$ のみが投資を行い，企業 $L$ は投資をしないという戦 略の組が均衡戦略となっている. オプションを考慮したベースケースでの結果と比較すると， 時点 0 では投資を見合わせる企業（企業 $L$ ） は，将来状況が好転した場合の投資の可能性を無 視していることから，自社の事業価值を過小評価しており，一方で，時点 0 で投資を行う企業 （企業 $F ） は ，$ 競合他社の投資の可能性を無視していることから，自社の事業価值を過大評価 していることがわかる. 


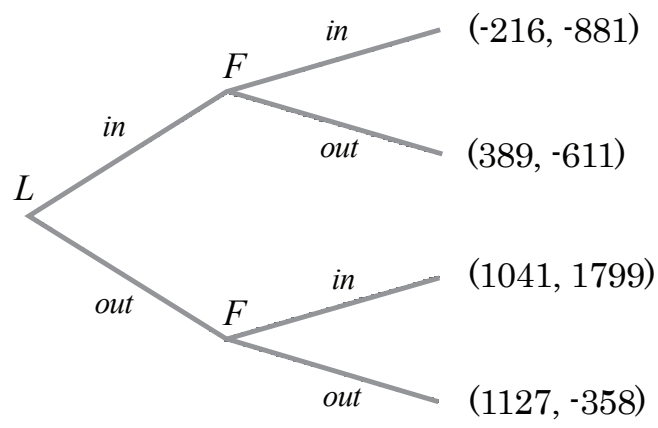

事業価値 （企業 $L$,企業 $F$ )

図 3: オプションを考慮しないときの事業価值

\section{5 感度分析}

\section{1 幾何ブラウン運動トレンド項（市場成長）を変化させたシミュレーション}

図 4 と図 5 にそれぞれ需要トレンドを変化させたときの事業価值と投資確率を示す.

今回のシミュレーションでは，投資規模は企業 $L$ が 3 ライン，企業 $F$ が 1 ラインとした. こ こで，トレンド項が $2.5 \%$ となったころで，企業 $L$ の事業価值が企業 $F$ の事業価值を上回っ ている.しかし, 企業 $L$ の投資確率の方は, トレンド項が $2.5 \%$ でもまだ $100 \%$ には至らず, $14.5 \%$ となったところでようやく $100 \%$ に到達する.

これは，企業 $L$ にって，今回の前提に置いた投資規模が市場成長に見合うためには，14.5\% 程度のトレンドが必要であることを示している，すなわち，3 ラインの投資に見合う市場成長 はそれなりに大きなものが必要になることを示している.

一方，企業 $F$ の方は 1 ラインの投資を前提としたため，企業 $L$ と比較して小規模な投資であ り, 市場成長が大きくなくても企業 $L$ に比べて過大なロスが発生しない状況であり, この結果 として投資確率は $100 \%$ に達している.

すなわち, 企業 $L$ が市場成長よりも過大な投資を検討している場合, 企業 $F$ は小規模な投資 で自らの事業価值を高めることができる，しかし，市場成長が大きくなり，企業 $L$ の投資規模

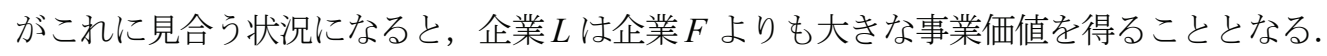

\section{2 幾何ブラウン運動ボラティリティ項を変化させたシミュレーション}

図 6 に需要のボラティリティを変化させた場合の企業 $L$, 企業 $F$ 双方の事業価值を示す. 標 準データセットでのボラティリティは $17.6 \%$ である.

ボラティリティを大きくしていくと企業 $L$, 企業 $F$ の双方とも事業価值は下がっていく．こ の理由を図 7 に概念図で示す。縦軸 $Y$ は需要量, 横軸 $t$ は時間である. 今回のシミュレーショ 
堀内 晃・磯部 航太・茂木 源人

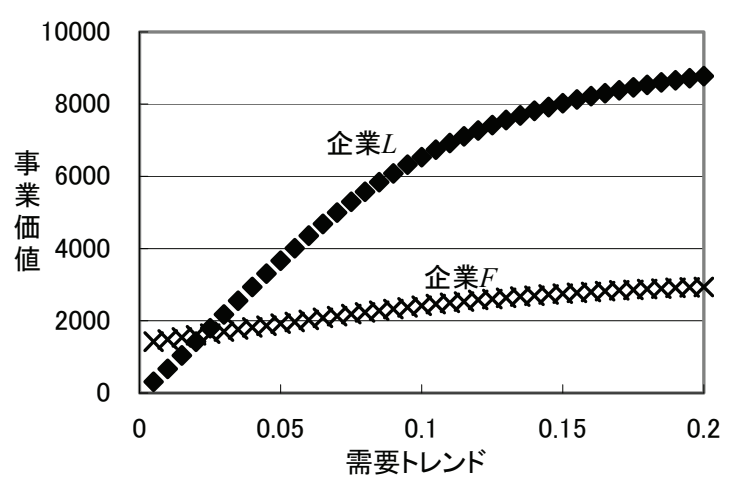

図 4: 需要のトレンドを変化させたときの事業価值

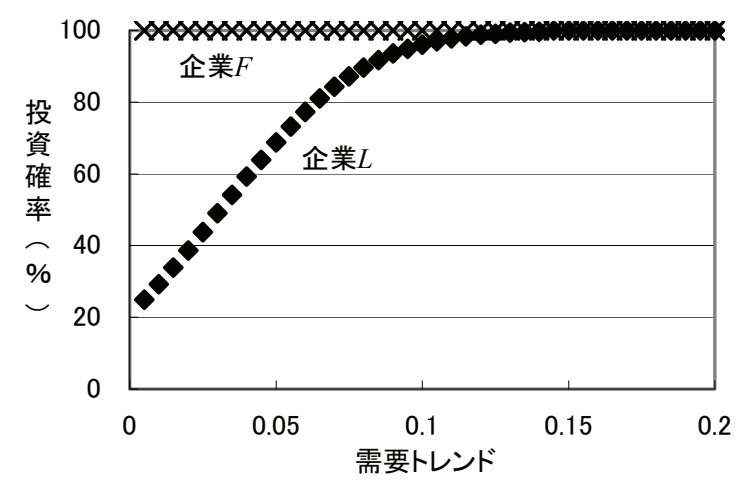

図 5: 需要のトレンドを変化させたときの投資確率

ンにおいては，企業 $L ，$ 企業 $F$ ともに製造量の上限を決めている．ボラティリティが小さい時 （ $Y_{1}$ を始点とした点線のような場合）は製造能力上限にかからずにそのまま需要量が供給され 事業価值に反映される。しかし，ボラティリティが大きいと（ $Y_{1}$ を始点とした実線のような場 合), 需要量が多い方に振れて製造能力上限を超えた部分（濃い灰色の領域）は，需要をまかな いきれなくなり，その分だけ事業価值が減る．また，時点ゼロでの需要量が $Y_{2}$ のように初めか ら製造能力上限に近い場合は， $Y_{1}$ の場合よりも早い時点で製造量が抑えられ (薄い灰色の領域), 事業価值が減少することになる。図 6 では少しでもボラティリティが大きくなった状態から企 業 $L$, 企業 $F$ ともに事業価值が減少している.この理由は，今回標準データセットで設定した $Y_{0}$ に基づいて両企業ともに最適戦略を選択するので，需要量にマッチするような製造能力とな るように投資行動を決めているためである.

図 6 においてボラティリティが小さいときは, 企業 $L$ の方が企業 $F$ よりも事業価值が大きく,

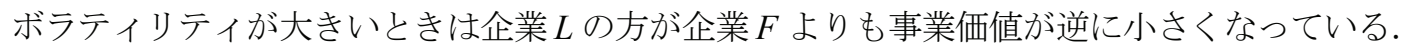


市場が安定している場合，企業 $L$ の事業価值は企業 $F$ よりも大きい製造能力が十分に活かされ ることにより，企業 $F$ よりも大きくなる．しかし，需要量が大きくばらつく場合は，上述と同 じく製造量が少なくなった場合すなわち収益が良くない場合の事業価值の方が強く影響してし まい，企業 $L$ の事業価值は企業 $F$ よりも小さくなってしまう。このことから，本事例における 企業 $L$ のような製造能力と固定費用係数の大きい企業は，需要量の変化が大きい場合，これに 追随することが難しいことが判る.

図 8 に需要のボラティリティを変化させた場合の企業 $L$, 企業 $F$ 双方の投資確率を示寸. 標 準データセットでの投資確率は企業 $L$ が $38.5 \%$ ，企業 $F$ が 100\%である.

企業 $F$ の投資確率はボラティリティが変化しても $100 \%$ のまであるが，企業 $L$ の投資確率 は $100 \%$ になる場合はなく，極大值が存在する．さらにボラティリティが限りなく 0 に近い場 合，企業 $L$ の投資確率は $0 \%$ になている．これは，今回設定したトレンドで市場がボラティ リティ=ゼロで安定して成長する場合, 企業 $L$ は今回設定した事業期間 25 年に渡って常に投資 を行わない方が大きな事業価值を得られることを示している．今回シミュレーションした範囲 では，企業 $L$ の投資確率は $100 \%$ になる場合がないので，時点 0 での企業 $L$ の最適戦略は投資 を行わず延期することである．また，極大值があることから，幾分でも投資をした方が事業価 值が大きくなる場合が将来あり得る中で，ボラティリティが $20 \%$ 程度のときが最もその確率が 高くなる，ということになる.

企業 $L$ の投資確率はトレンド項のところで述べたように，投資しようとしているライン数が 需要の拡大量に見合っていないので，延期する確率の方が高いことを示している．一方で企業 $F$ の投資は大きくないため,ためらわずに時点 0 の段階で投資をすることが確実な情勢である.

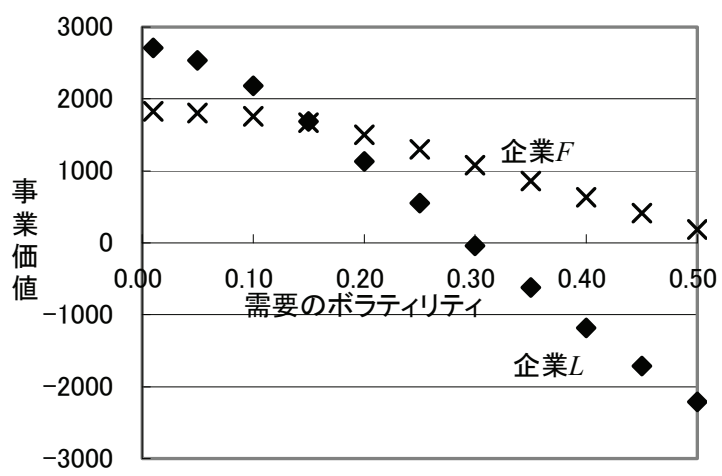

図 6: 需要のボラティリティを変化させたときの事業価値 


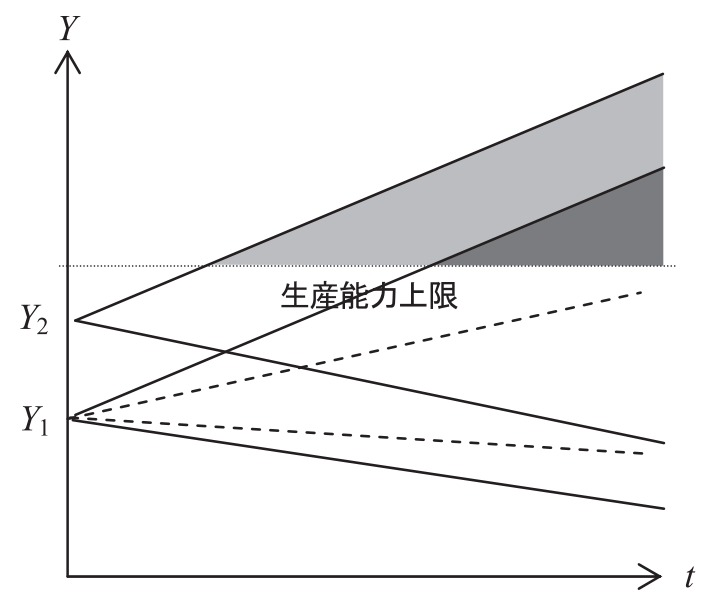

図 7：初期需要量およびボラティリティと事業価值の関係図

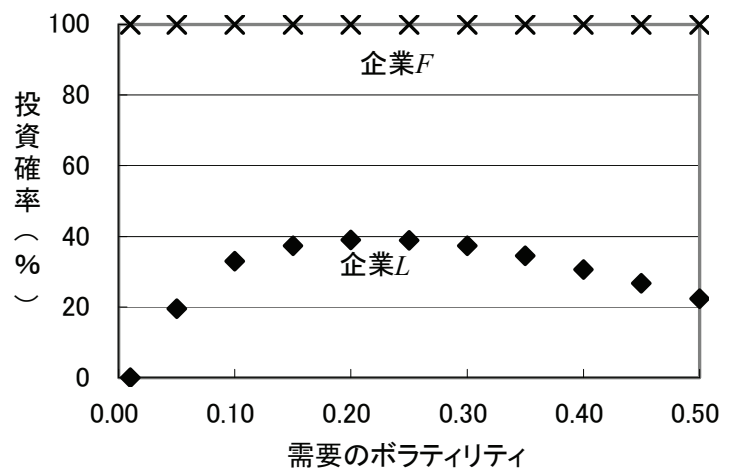

図 8: 需要のボラティリティを変化させたときの投資確率

\section{3 固定費用係数を変化させたシミュレーション}

\subsection{1 リーダー企業から見た場合}

図 9 と図 10 に企業 $L$ の事業価值, 投資確率を示す. 横軸が企業 $F$ の固定費用係数, 縦軸が 企業 $L$ の固定費用係数である. 図 11 と図 12 はこれを立体的に図示したものである.

事業価值と投資確率のいずれも横縞状のグラフになっている. すなわち, 企業 $L$ の事業価值 および投資確率は，横軸である企業 $F$ の固定費用係数が変化してもほとんど影響されない. 単 純に企業 $L$ 自身の固定費用係数が低いときに高い事業価值または投資確率が得られ，逆に固定 費用係数が高いときに低い事業価值または投資確率となることが判る.

このことから，企業 $L$ は自分の事業価值を高めるために，固定費については自らの固定費低 減策を進めていく戦略のみを考えれば良いことが判る。この状態では企業 $F$ がいくら固定費低 
減の戦略を積極的に進め, この実績効果を得たとしても, 企業 $L$ は自らの投資確率や事業価值 は変化しないので，戦略を劦かされない。

なお, 図 10 において, 企業 $L$ の固定費用係数（縦軸）が $30 \%$ で, 企業 $F$ の固定費用係数（横 軸)が 100\%の付近に, 企業 L の投資確率が 100\%ではない領域が離れ小島のように現れている. ここの領域は，企業 $L$ の投資確率が非常にクリティカルな状態の領域で，投資をした場合とし ない場合のキャッシュフローが接近した状態となっているため，このような計算結果になった と考えられる.

\subsection{2 フォロワー企業から見た場合}

図 13 と図 14 に企業 $F$ の事業価值, 投資確率を示す. 横軸が企業 $F$ の固定費用係数, 縦軸が 企業 $L$ の固定費用係数である. 図 15 と図 16 はこれを立体的に図示したものである.

事業価值と投資確率のいずれも縦軸 $40 \%$ の付近（企業 $L$ の固定費用係数が $40 \%$ の付近）に変

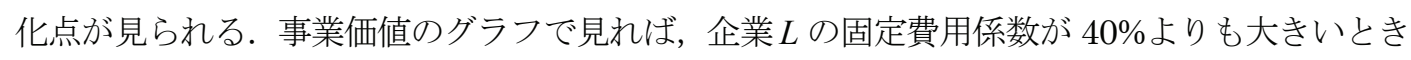
は，小さいときよりも企業 $F$ の事業価值が自らの固定費用係数を下げることによる改善効果が 大きい. 投資確率のグラフで見ると, 企業 $L$ の固定費用係数が $37.5 \%$ から $40 \%$ の付近に急激な 変化点があり，これより企業 $L$ の固定費用係数が大きくなると企業 $F$ の投資確率は一気に $100 \%$ となる。

このことから, 企業 $F$ は自らの事業価值および投資確率を高めるために, 固定費の低減策を 進めることは有用であるが，企業 $L$ の固定費用係数が高いとき（固定費負担が重いとき）に， より一層その効果が高まる.

\subsection{3 双方の最適戦略}

企業 $L$ の固定費負担が小さく, それを維持改善し続けている場合は, 企業 $F$ はなかなか付け 入る隙がない. よって, 企業 $L$ の最適戦略は, 企業 $F$ に隙を与えないように, 常に低い固定費 用係数を維持改善し続けることである.

企業 $F$ の最適戦略は, 自らの固定費負担を着実に改善しつつ, 企業 $L$ の固定費負担が重いと 判断された場合は積極的に拡張投資を行い，逆に固定費負担が軽いと判断された場合は，自ら の固定費負担を着実に改善するのは当然であるが，何らかの理由から企業 $L$ の固定費が悪化す るといった隙ができるのを待ち，投資する機会を伺うことになる. 


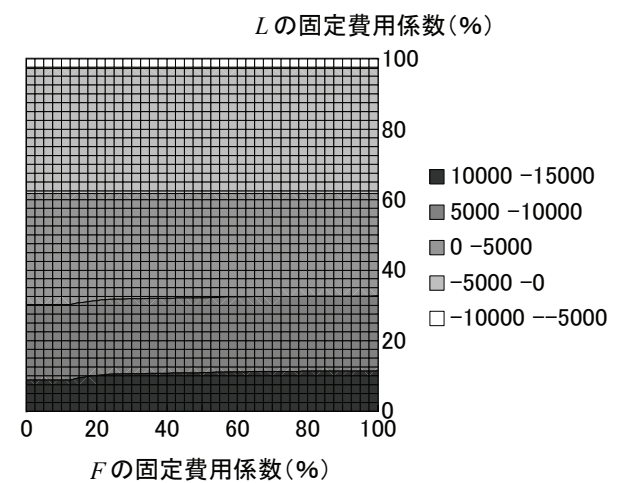

困 9: 企業 $L$ の事業価值

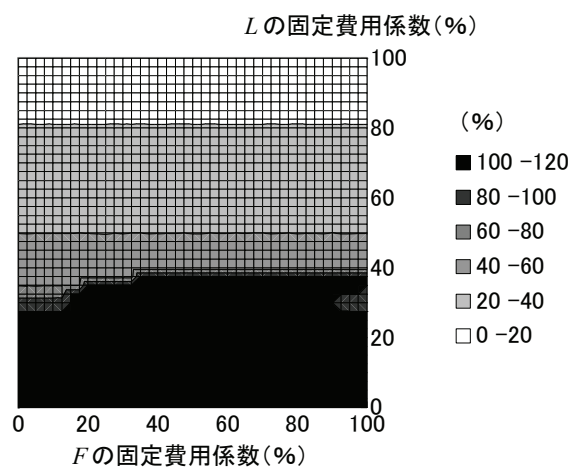

図 10：企業 $L$ の投資確率

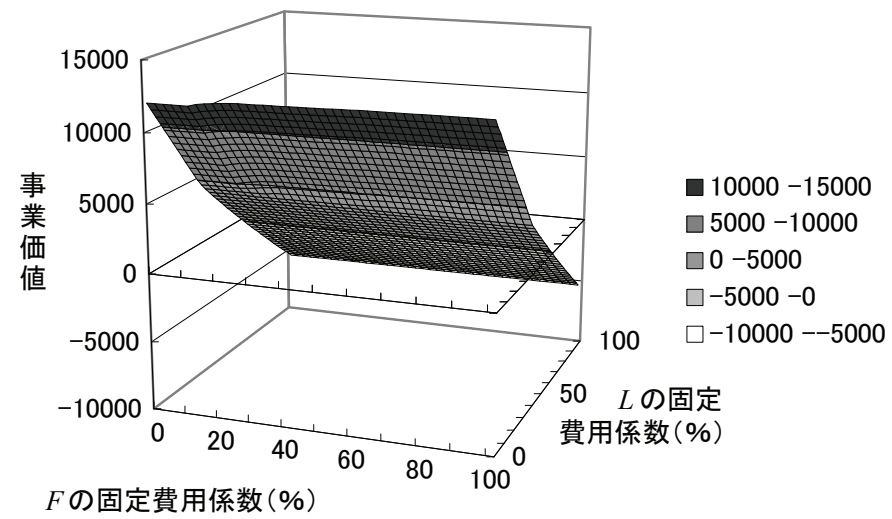

図 11：企業 $L$ の事業価值

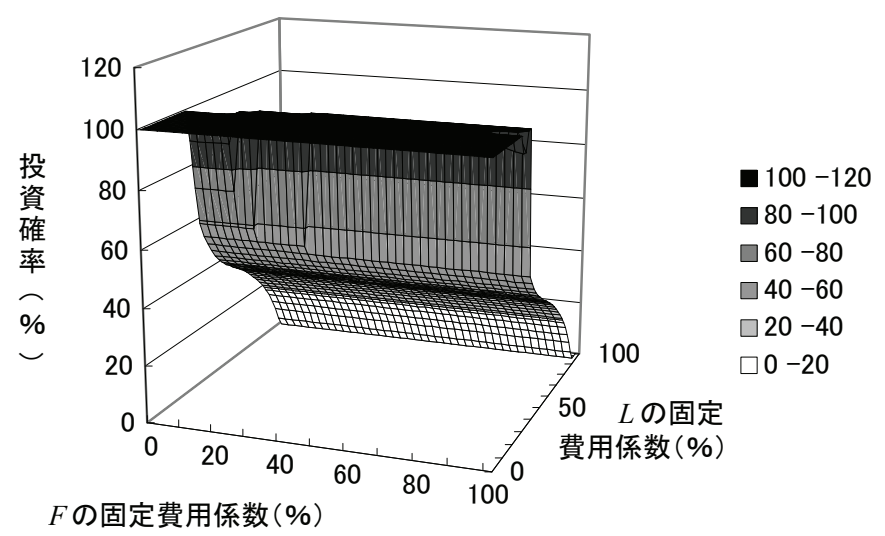

図 12：企業 $L$ の投資確率 


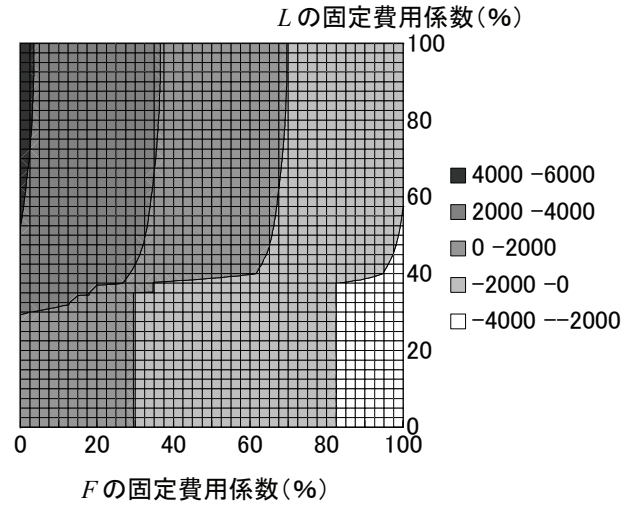

図 13: 企業 $F$ の事業価值

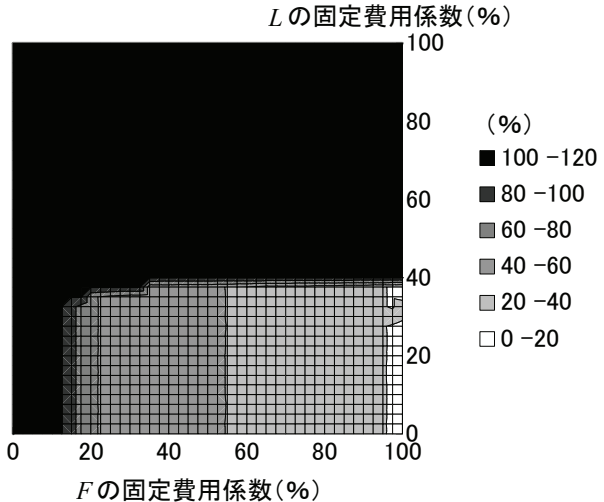

図 14：企業 $F$ の投資確率

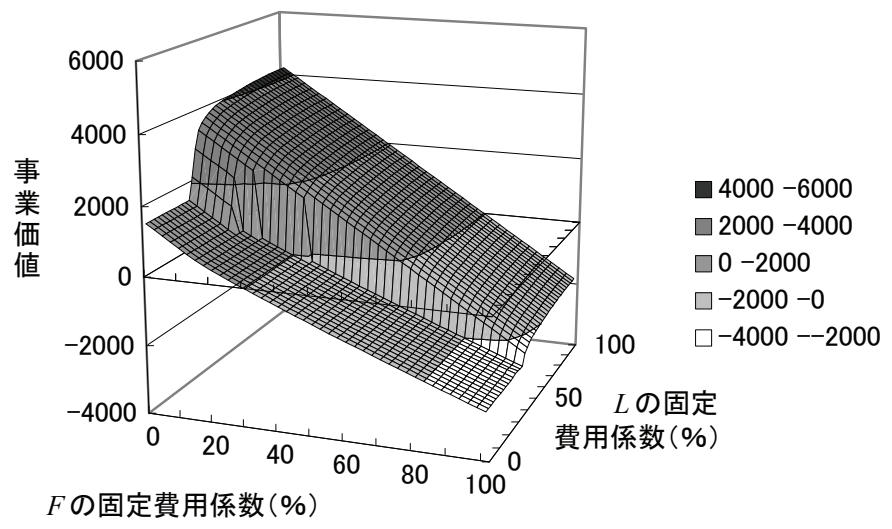

図 15: 企業 $F$ の事業価値

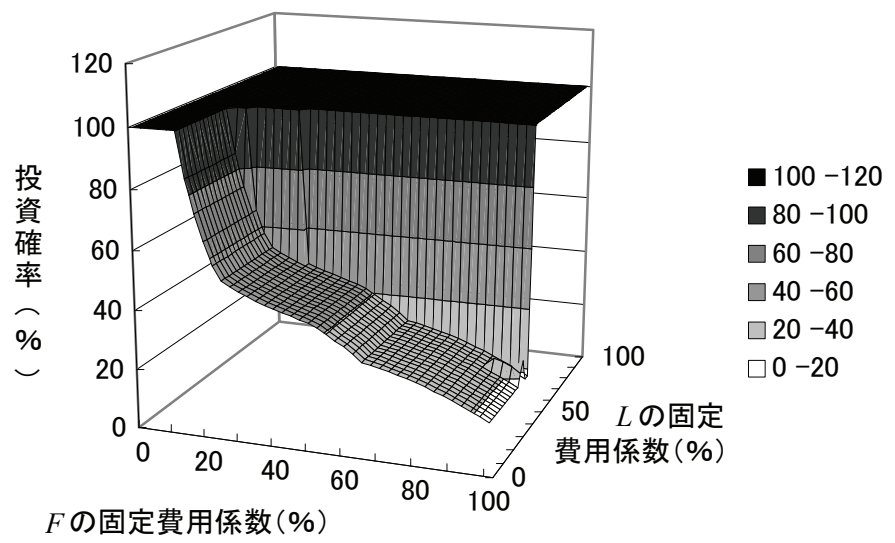

図 16: 企業 $F$ の投資確率 


\section{堀内 晃・磯部航太・茂木 源人}

\section{4 変動費を変化させたシミュレーション}

\subsection{1 リーダー企業から見た場合}

図 17 と図 18 に企業 $L$ の事業価值，投資確率を示す.横軸が企業 $F$ の製造 1 単位あたりの利 益, 縦軸が企業 $L$ の製造 1 単位あたりの利益である. 図 19 と図 20 はこれを立体的に図示した ものである. 本稿では, 販売価格を一定としたため, 変動費の減少は製造 1 単位あたりの利益 の上昇を, 変動費の増加は製造 1 単位あたりの利益の減少を示す.

固定費用係数で見たときと同様, 事業価值と投資確率のいずれも横縞状のグラフになっている. すなわち, 企業 $L$ の事業価值および投資確率は, 横軸である企業 $F$ の変動費が変化しても, ほ とんど影響されない. 単純に企業 $L$ 自身の変動費が低いときに高い事業価值または投資確率が 得られ，逆に変動費が高いときに低い事業価值または投資確率となる. 固定費用係数の場合と 同じく, 企業 $L$ は自分の事業価值を高めるために, 変動費についても自らの変動費低減策を進 めていく戦略のみを考えれば良いことが判る。この状態では企業 $F$ がいくら変動費低減の戦略 を積極的に進め, この実績効果を得たとしても, 企業 $L$ は自らの投資確率や事業価值は変化し ないので，戦略を劦かされない。

\subsection{2 フォロワー企業から見た場合}

図 21 と図 22 に企業 $F$ の事業価值，投資確率を示す. 横軸が企業 $F$ の製造 1 単位あたりの利 益, 縦軸が企業 $L$ の製造 1 単位あたりの利益である. 図 23 と図 24 はこれを立体的に図示した ものである。

事業価值および投資確率のいずれのグラフも全体的には縦縞状の分布を呈しているが，グラフ の途中で分布が大きく屈曲している，投資確率のグラフで見た場合，縦軸である企業 $L$ の製造 1 単位あたりの利益が 20 より低くなると, 企業 $F$ の投資確率が $100 \%$ にる領域が存在するが, 逆に 20 より大きくなると，企業 $F$ の投資確率が $80 \%$ 未満の領域が広くなっている.

これより, 企業 $F$ は自らの事業価值および投資確率を高めるために, 変動費の低減策を進め ることは有用であるが，企業 $L$ の変動費が大きいとき（製造 1 単位あたりの利益である縦軸が 小さいとき）に，自らの変動費の改善効果がより一層大きくなることが判る.

なお，図 22 で企業 $F$ の製造 1 単位あたりの利益（横軸）が 7 を下回ったとき，企業 $L$ の製 造 1 単位あたりの利益（縦軸）が 20 よりも小さくても急激に投資確率が低くなっている.こ の変化は三次元で図示した図 24 を見るとより明らかである. 企業 $F$ はいくら企業 $L$ の利益が 少なくても，自らの利益が少ないときは投資を見合わせるべきであるが，急激に投資確率が変 化する場所があるので，ここの見極めは重要になる. 
$L$ の生産1単位あたりの利益

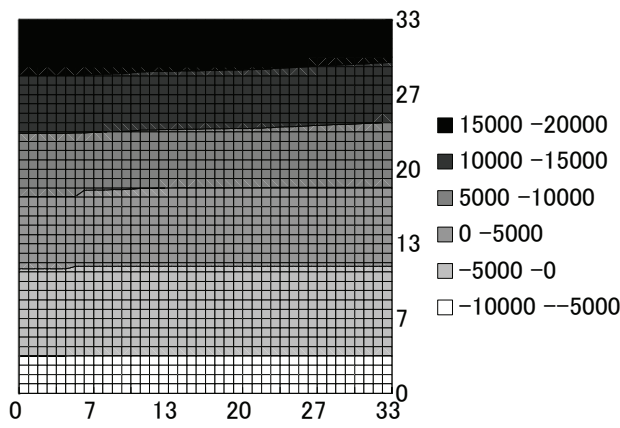

$F$ の生産1単位あたりの利益
$L$ の生産1単位あたりの利益

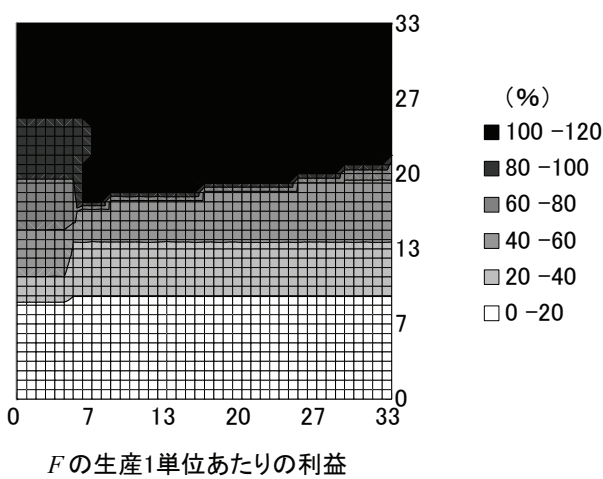

困 18：企業 $L$ の投資確率

図 17：企業 $L$ の事業価值

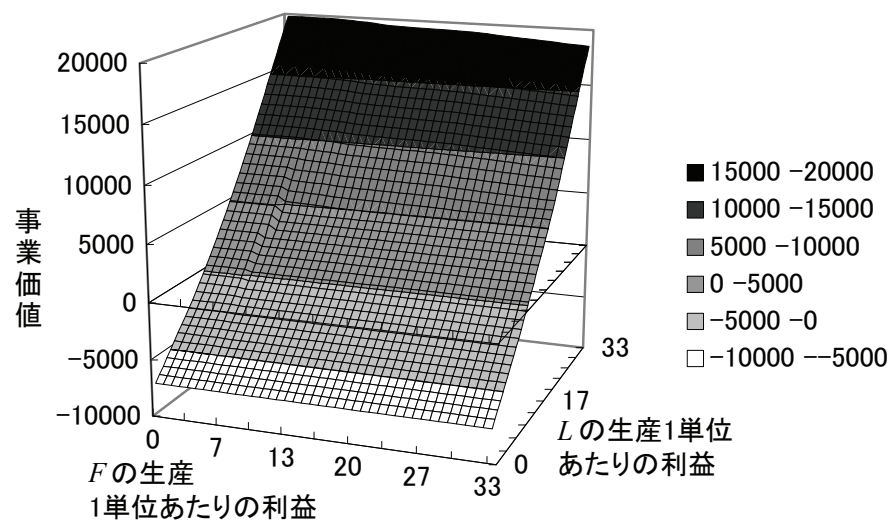

困 19: 企業 $L$ の事業価值

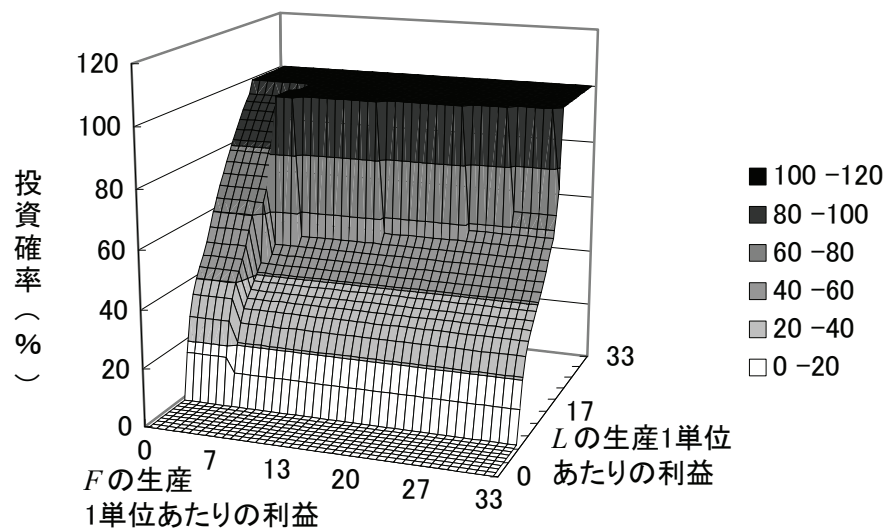

図 20：企業 $L$ の投資確率 
$L$ の生産1単位あたりの利益

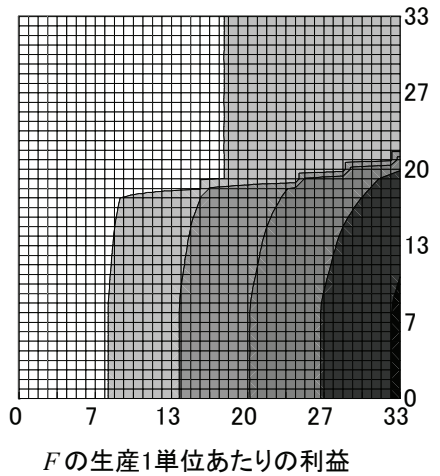

— $8000-10000$

- $6000-8000$

$\square 4000-6000$

$\square 2000-4000$

$\square 0-2000$

$\square-2000-0$

図 21：企業 $F$ の事業価值

$L$ の生産1単位あたりの利益

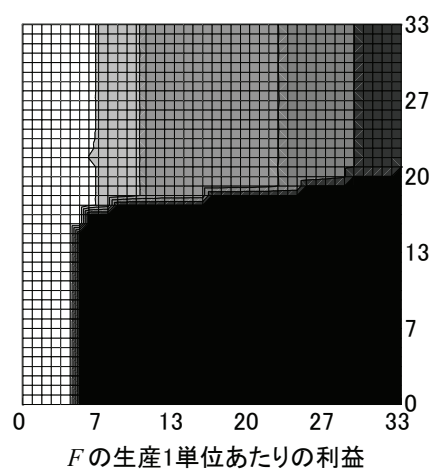

(\%)

- $100-120$

口 $80-100$

$\square 60-80$

$\square 40-60$

$\square 20-40$

$\square 0-20$

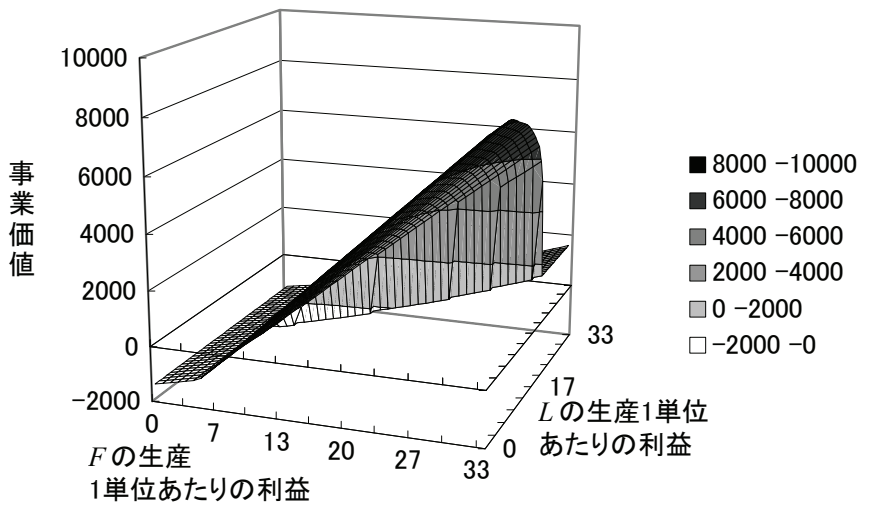

図 23: 企業 $F$ の事業価值

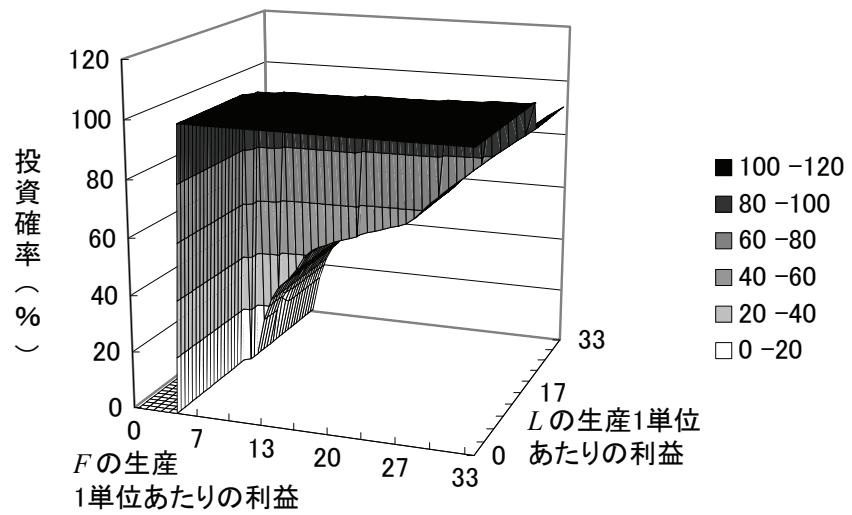

図 24：企業 $F$ の投資確率 
一方で, 図 22 における企業 $F$ の投資確率の低い領域を企業 $L$ の側から考えると, 図 18 にお ける企業 $F$ の製造 1 単位あたりの利益（横軸）が 7 よりも小さいときに相当する. この領域で は企業 $L$ は企業 $F$ が投資をしてこない状態であるので, 相手のことを考えなくても良く, 単純 に自らの利益が多くなるのに従って，投資確率が高くなっている.

また, 図 18 において, 企業 $F$ の製造 1 単位あたりの利益（横軸）が 7 よりも大きい領域で は, 企業 $L$ の投資確率が $100 \%$ 範囲が下へせり出している. この状態は, 企業 $F$ の側の収益 性が良くなり積極投資に出てくる状態になるので，企業 $L$ は投資をしなければ利益が維持でき なくなっている状態である. このことは図 17 と図 18 を比べてみると明らかで, 投資確率の線 は変化が大きいが, 事業価値の方はほぼ一様に横縞模様になっている. 言い換えると, 企業 $L$ の 方は積極的に投資をしないと事業価值が維持できない状況となっており, ここの領域では防衛 的な投資戦略に出ていることになる.

さらには，横軸で 7 の位置を縦に見ていくと，縦軸の值が 0 から大きくなっていくにつれて 企業 $L$ の投資確率は高くなっていき, 17 付近で $100 \%$ に達する. しかし, 20 を超えた辺りで逆 に 80-100\%まで一旦低くなり, その後 27 程度になったところで再度 $100 \%$ に戻るという挙動 を示している，このように，一旦投資確率が低くなるという理由は，企業 $F$ の投資確率に原因 がある. 図 22 によれば，同じく横軸で 7 の位置において，企業 $F$ の投資確率は縦軸の值が 17 を超えた辺りで急激に低くなり，20\%未満となっている，つまり，ここでは企業 $F$ は収益性が さほど良くなく，企業 $L$ が投資をしない場合でもあまり積極的に投資に出てこない状態である ので，企業 $L$ は自らの投資にやや延期の確率が生じている状態である.

\subsection{3 双方の最適戦略}

企業 $L$ の変動費負担が小さく, それを維持改善し続けている場合は, 企業 $F$ はなかなか付け 入る隙がない. よって, 企業 $L$ の最適戦略は, 企業 $F$ に隙を与えないように, 常に低い変動費 を維持改善し続けることである。

企業 $F$ の最適戦略は，自らの変動費負担を着実に改善しつつ，企業 $L$ の変動費負担が自身よ りも重いと判断された場合は積極的に拡張投資を行い，逆に変動費負担が自身よりも軽いと判 断された場合は, 何らかの理由から企業 $L$ の変動費の改善が相対的に遅れる, あるいは悪化す るといった隙ができるのを待ち, 投資拡大戦略に打って出る機会を伺うことになる.

\section{6 まとめ}

成熟産業と目される米国や日本のステンレス鋼製造業において，その生き残り策の一つとし 
て, ステンレス鋼に比べれば市場が小さく, 先行メーカーの数も少なく, しかしながらある程 度の成長が見込まれる特殊合金に，製品構成の一部をシフトしていく戦略が考えられる，そこ で，このような特殊合金市場として，二社の複占状態の市場を想定し，二社双方が生産量の拡 大投資を行う場合の最適戦略を, 各種パラメータを多様に変化させることによって導き出した. この二社の事業評価を行うのにあたり，設備拡張プロジェクトのリアルオプション評価手法と して，モンテカルロ法の一つである SSA 法を応用して開発した。 その際，両社の最適戦略を求 めるために，ゲーム理論における均衡の概念を適用した.

二社の複占状態を形成する市場の実例として, LNG タンカー用メンブレン材料市場を取り上 げ，その製造事業価值を最大化する最適戦略を求めた。

ここでそれぞれの需要環境のもとでの設備拡張の投資確率分布が求められた.

得られた結果を基に，以下の 4 つの変数について感度分析を行った.

○需要のトレンド

○需要のボラティリティ

○製造固定費用係数

○製造 1 単位あたりの利益

この結果, リーダー企業とフォロワー企業のそれぞれの最適戦略の変化が求められた. リー ダーの最適戦略は，フォロワーの戦略によって影響を受けないが，フォロワーに対して隙を与 えないように，常にコストを低く維持改善していく必要がある，一方，フォロワーの最適戦略 は, 次の 3 点である.

・自らのコストを着実に維持改善すること

・リーダーのコスト負担が十分に重いと判断された場合は積極的に拡張投資を行うこと

・逆にリーダーのコスト負担が相対的に低いと判断された場合は，需要が十分に拡大する， あるいは何らかの理由によりリーダーのコスト改善が遅れる，または悪化するといった隙 ができるまで拡張投資を行わずに待つこと

\section{参考文献}

[1] Barraquand, J. and Martineau, J. (1995). Numerical valuation of high dimensional multivariate American securities. Journal of Financial and Quantitative Analysis, 30, 383-405.

[2] Dixit, A. K. and Pindyck, R. S. (1994). Investment under Uncertainty. Princeton University Press, Princeton. 
[3] Fudenberg, D. and Tirole, J. (1985). Preemption and rent equalization in the adoption of new technology. The Review of Economic Studies, 52, 383-401.

[4] Grenadier, S. R. (1996). The strategic exercise of options: Development cascades and overbuilding in real estate markets. Journal of Finance, 51, 1653-1679.

[5] Huisman, K. J. M. (2001). Technology and Investment: A Game Theoretic Real Option Approach. Kluwer Academic Publishers.

[6] Imai, J. and Watanabe, T. (2005). A multi-stage investment game in real option analysis.

[7] Murto, P., Näsäkkälä, E. and Keppo, J. (2004). Timing of investments in oligopoly under uncertainty: A framework for numerical analysis. European Journal of Operational Research, 157, 486-500

[8] Smit, H. T. J. and Ankum, L. A. (1993). A real options and game-theoretic approach to corporate investment strategy under competition. Financial Management, 22, 241-250.

[9] Weeds, D. (2002). Strategic delay in a real options model of R\&D competition. The Review of Economic Studies, 69, 729-747.

[10] 安達毅, 茂木源人，足達哲男（2008）。“改良 SSA 法による多段階投資からなる資源開発 プロジェクトのリアルオプション分析”。「資源・素材学会誌」, 124, 576-582.

[11］湯前祥二，鈴木輝好 (2000).「モンテカルロ法の金融工学への応用」，朝倉書店. 